\title{
Silage extracts used to study the mode of action of silage inoculants in ruminants
}

\author{
Richard E. Muck ${ }^{1 *}$, Zwi G. Weinberg ${ }^{2}$ and Francisco E. Contreras-Govea ${ }^{3}$ \\ ${ }^{1}$ USDA, Agricultural Research Service, US Dairy Forage Research Center, 1925 Linden Drive, Madison, Wisconsin, \\ 53706 United States \\ ${ }^{2}$ The Volcani Center, Bet Dagan, Israel \\ ${ }^{3}$ University of Wisconsin-Madison, Madison, Wisconsin, United States \\ *e-mail: richard.muck@ars.usda.gov
}

\begin{abstract}
Lucerne and two maize crops were ensiled with and without Lactobacillus plantarum and fermented for 4 or $60 \mathrm{~d}$ to assess the effect of inoculant on in vitro rumen fermentation of the resulting silages. Water and $80 \%$ ethanol extracts of the silages were also analysed for effects on in vitro rumen fermentation. The inoculant affected lucerne silage characteristics but had little effect on the maize silages. In vitro fermentation of the silages showed few effects except increased microbial biomass yield (MBY) at $24 \mathrm{~h}$ in the inoculant-treated lucerne silages. In vitro fermentation of the lucerne silage water extracts produced no differences due to treatment except for reduced MBY in the inoculant-treated extracts. The ethanol extracts produced results inconsistent with the in vitro results of the silages. Consequently it appears that the factor in in vitro fermentation of inoculated silages causing increased MBY was in neither the water nor ethanol extracts.
\end{abstract}

Key words: inoculant, in vitro fermentation, silage, microbial biomass yield, gas production

\section{Introduction}

Microbial silage inoculants are additives used to improve silage fermentation (Muck and Kung 1997). These additives also may increase milk production or daily gain in livestock, but the mechanisms are unknown (Weinberg and Muck 1996, Kung and Muck 1997). The most common silage inoculants contain facultative heterofermentative lactic acid bacteria (LAB) that shift fermentation toward lactic acid production, reducing acetic acid and ethanol. Based on analysis of data from 47 experiments, a $10 \mathrm{~g} \mathrm{~kg}^{-1} \mathrm{DM}$ increase in lactic acid and $10 \mathrm{~g} \mathrm{~kg}^{-1} \mathrm{DM}$ reduction in acetic acid should increase energy-corrected milk by $0.12 \mathrm{~kg} \mathrm{~d}^{-1}$ (Huhtanen et al. 2003). Inoculants often reduce ammonia in silages. That is also correlated to higher milk production; a $10 \mathrm{~g} \mathrm{~kg}^{-1} \mathrm{~N}$ reduction in ammonia would be expected to increase energy-corrected milk by $0.19 \mathrm{~kg} \mathrm{~d}^{-1}$ (Huhtanen et al. 2003). Sometime inoculants reduce the amount of fermentation products, and that should have a positive effect on milk production (Huhtanen et al. 2003, Jaakkola et al. 2006). Unfortunately, the expected improvement in milk production from all of these shifts in silage composition are much less than the observed average improvement in milk production $\left(1.4 \mathrm{~kg} \mathrm{~d}^{-1}\right) \mathrm{from}$ feeding inoculated silage (Kung and Muck 1997). Consequently, changes in common silage characteristics due to silage inoculant use cannot explain the magnitude of improvements in milk production observed.

Recent research is providing evidence, suggesting possible means by which inoculants may alter animal responses to treated silages. Two studies indicated that lactic acid bacteria survived in rumen fluid and resulted in small but consistent increases in pH (Weinberg et al. 2003, Weinberg et al. 2004), which should be beneficial to cell walldegrading microorganisms in the rumen. In addition, nine of ten inoculant LAB exhibited antimicrobial activity when grown in broth, and the majority of extracts of silages treated with these inoculants also had antimicrobial activity (Gollop et al. 2005). In experiments comparing 14 inoculants, none of the inoculants had a positive effect on in vitro dry matter digestibility (IVDMD) (Filya et al. 2007). In contrast, in vitro gas production (GP) on undried silages from those experiments was reduced in many of the inoculated silages compared to untreated control silages while only minor effects on volatile fatty acid (VFA) production were observed (Muck et al. 2007). The reduced GP suggested that inoculated silages were producing more rumen microbial biomass yield (MBY) than untreated silage. Recently, Contreras-Govea et al. (2011) reported on three ensiling experiments (lucerne and two whole-crop maizes), comparing untreated and four different microbial inoculants. In this study, there were few differences in silage fermentation characteristics among inoculated and untreated silages, but in the in vitro rumen 
fermentations, silages from two of the inoculants consistently produced more MBY than the corresponding untreated silages. Furthermore the increase in MBY was of an order that could explain the 3 to $5 \%$ increase in milk production observed in cow studies (Kung and Muck 1997). These studies suggest that the effects of inoculated silages on animal performance are due to changes in rumen microbial fermentation by an unknown mechanism.

The objective of the current experiment was to determine if extracts from silages treated with Lactobacillus plantarum would affect GP, MBY and VFA production from in vitro fermentation similarly to the in vitro fermentation of the silages. The hypothesis was that the factor in inoculated silage that enhances rumen microbial growth should be extractable from silage.

\section{Materials and methods}

Third cut of a second year lucerne (580 g dry matter (DM) kg ${ }^{-1}$ ) was harvested on 31 August 2010 after field wilting for approximately $24 \mathrm{~h}$, and two maize crops were harvested, one with low DM concentration $\left(<300 \mathrm{~g} \mathrm{DM} \mathrm{kg}^{-1}\right.$, Maize-LDM) on 27 August 2010 and one with high DM concentration ( $500 \mathrm{~g} \mathrm{DM} \mathrm{kg}^{-1}$, Maize-HDM) on 7 September 2010. The forages were chopped with a conventional precision-chop forage harvester and ensiled individually in 1-I glass jar mini-silos (Weck, Wher-Oftlingen, Germany) at a density of $500 \mathrm{~g} \mathrm{l}^{-1}$ with two treatments: untreated control and Lactobacillus plantarum (LP, Ecosyl MTD/1, Ecosyl, North Yorkshire, UK) at $10^{6} \mathrm{cfu} \mathrm{g}^{-1}$ of fresh weight, six mini-silos per treatment. During ensiling three samples of each crop and a sample of the inoculant were taken for enumeration of LAB by Rogosa SL agar (Muck and Dickerson 1988). Three mini-silos of each treatment were frozen $\left(-20^{\circ} \mathrm{C}\right)$ after 4 and $60 \mathrm{~d}$ of fermentation until analysed. At opening, each mini-silo was poured into a disinfected plastic pan and mixed to uniformity. A 20 g sample was taken, diluted 10-fold with distilled water, and macerated for $30 \mathrm{~s}$ in a high-speed blender. Silage extract was filtered through 4 layers of cheesecloth, and $\mathrm{pH}$ was measured immediately using a $\mathrm{pH}$ meter. One $20 \mathrm{ml}$ aliquot sample was placed in a $50 \mathrm{~mL}$ polypropylene tube, centrifuged for $20 \mathrm{~min}$ at $25,100 \times \mathrm{g}$ at $4^{\circ} \mathrm{C}$, and the supernatant decanted into a $20 \mathrm{ml}$ scintillation vial and frozen at $-20{ }^{\circ} \mathrm{C}$ for later analysis of fermentation products. Fermentation products (succinate, lactate, acetate, propionate, butyrate, and ethanol) were performed using high performance liquid chromatography (Muck and Dickerson 1988). Two silage sub-samples of approximately $50 \mathrm{~g}$ each were taken for moisture analysis by freezedrying. The freeze-dried silage samples were ground to $1 \mathrm{~mm}$ and used for the determination of neutral detergent fibre (aNDF) analysis, with heat stable amylase and sulphite, using an ANKOM fibre analyser (Ankom Technology Corp., Fairport, NY, USA).

The remaining fresh silage from each mini-silo was chopped to a particle size of 1-4 $\mathrm{mm}$ using a commercial food processor (Robot Coupe, Inc., Joliet, IL, USA) for $30 \mathrm{~s}$ and stored at $-20^{\circ} \mathrm{C}$ for later analysis of in vitro rumen fermentation. The MBY and VFA production in $50 \mathrm{ml}$ polypropylene plastic tubes and GP in $160 \mathrm{ml}$ bottles were determined on these wet-ground silages, as described previously (Contreras-Govea et al. 2011). The rumen fluid was collected from four rumen cannulated lactating cows in the morning before feeding, following the procedure described by Weimer et al. (2005). Donor cows were fed a TMR diet of 50:50 forage (corn silage and alfalfa silage): concentrate. Gas production, VFA and MBY were measured after 9 and $24 \mathrm{~h}$ incubation at $39^{\circ} \mathrm{C}$. The MBY was calculated by the difference of in vitro apparent digestibility and in vitro true DM digestibility (Blümmel et al. 1997).

In addition, 1:1 aqueous and $80 \%$ ethanol extracts of wet-ground control and inoculated silages were prepared to study their effects on in vitro ruminal MBY and GP. Ethanol was removed from the ethanol extracts by vacuum centrifuge, and the extract reconstituted with Type 1 water. Rumen fluid was prepared as above. Each tube or bottle contained $12 \mathrm{ml}$ rumen fluid, $17 \mathrm{ml}$ buffer, $1 \mathrm{ml}$ extract and $2 \mathrm{mg} \mathrm{ml}^{-1}$ glucose, which was the primary carbon source for the rumen microorganisms. In an additional in vitro treatment, L. plantarum suspension was added in place of extract to the buffered rumen fluid at $10^{6} \mathrm{cfu} \mathrm{ml}^{-1}$.

The silage fermentation data were analysed as a $3 \times 2 \times 2$ factorial experiment (crop $\times$ treatment $\times$ fermentation time) and the silage extract data were analysed as a $3 \times 2 \times 2 \times 2$ factorial experiment (crop $\times$ treatment $\times$ fermentation time $\times$ extract treated) using the PROC Mixed procedure of SAS (SAS Inst. Inc., Cary, NC, USA). The direct application of $L$. plantarum to in vitro fluid was analysed separately from the silage extract results by a one-way analysis of variance with crop as the fixed effect. Differences among means were tested by using the LSMEANS statement with the PDIFF option with significance declared at $p<0.05$. 


\section{Results \\ Silage fermentation}

The inoculant was applied at slightly above the intended rate, $6.06 \log _{10}$ (cfu g-1 crop). This rate was similar to the epiphytic population on Maize-LDM ( $\left.6.28 \log _{10}\left[\mathrm{cfu} \mathrm{g}^{-1} \mathrm{crop}\right]\right)$, but more than ten-fold higher than the LAB on the other two crops (4.81 $\log _{10}$ [cfu g-1 crop]). There were crop by treatment and crop by fermentation time interactions with regard to silage characteristics (Tables 1 and 2), but no crop by treatment by fermentation time interactions were found $(p>0.05)$, except for $\mathrm{pH}$ and ethanol concentration. These interactions were significant because the difference in $\mathrm{pH}$ between the two treatments in lucerne was much greater at day $4(0.478)$ than at day 60 (0.139) whereas there were no differences in $\mathrm{pH}$ between treatments on a given day for either maize except at day 4 in Maize-HDM (0.049). In the ethanol, LP-treated Maize-LDM at $4 \mathrm{~d}$ was similar to control (5.07 and 4.90 $\mathrm{g} \mathrm{kg}^{-1} \mathrm{DM}$, respectively), but at $60 \mathrm{~d}$ it was greater than control (15.09 and $9.69 \mathrm{~g} \mathrm{~kg}^{-1} \mathrm{DM}$, respectively); in contrast in the other two crops, no effects of treatment were observed at day 4 or 60 . The pH was lower in LP than control in lucerne but not the two maize silages (Table 1). Inoculant treatment effects on lactic acid concentration differed by crop. In lucerne, lactic acid concentration was $45 \%$ greater in LP than control while in both maize experiments, lactic acid was similar for both treatments (Table 1). Acetic acid concentration was different among crops $(p<0.001)$ and reduced by inoculant treatment. Maize-LDM had the greatest acetic acid concentration followed by Maize-HDM and lucerne (Table 1). Ethanol concentration in Maize-LDM was higher in LP than control while there was no effect of treatment on ethanol in the other two crops.

Table 1. Mean silage characteristics ( $\mathrm{g} \mathrm{kg}^{-1} \mathrm{DM}$ except as noted) by treatment across silage fermentation times.

\begin{tabular}{lccccccccccc}
\hline & \multicolumn{2}{c}{ Lucerne } & \multicolumn{2}{c}{ Maize-HDM } & \multicolumn{2}{c}{ Maize-LDM } & \multicolumn{2}{c}{ SEM } & \multicolumn{3}{c}{$p$-value } \\
Constituent & Control & LP & Control & LP & Control & LP & CXT & C & T & CXT \\
\hline $\begin{array}{l}\text { Dry matter } \\
\left(\mathrm{g} \mathrm{kg}^{-1}\right)\end{array}$ & 575 & 570 & 494 & 490 & 306 & 296 & 4.9 & $<0.001$ & 0.13 & 0.81 \\
aNDF & 345 & 350 & 401 & 393 & 376 & 360 & 11.7 & 0.001 & 0.55 & 0.66 \\
pH & 5.30 & 4.99 & 4.19 & 4.18 & 3.79 & 3.77 & 0.008 & $<0.001$ & $<0.001$ & $<0.001$ \\
Lactic Acid & 24.4 & 35.3 & 33.6 & 31.7 & 46.4 & 42.3 & 1.75 & $<0.001$ & 0.25 & 0.001 \\
Acetic Acid & 4.63 & 4.38 & 7.28 & 5.95 & 10.80 & 9.14 & 0.429 & $<0.001$ & 0.01 & 0.25 \\
Ethanol & 0.92 & 0.58 & 3.17 & 3.49 & 7.29 & 10.10 & 0.368 & $<0.001$ & 0.01 & 0.01 \\
\hline
\end{tabular}

${ }^{1} \mathrm{HDM}=$ high dry matter, $\mathrm{LDM}=$ low dry matter, $\mathrm{LP}=$ treated with Lactobacillus plantarum, $\mathrm{SEM}=$ standard error of the mean, $\mathrm{C}=$ crop,

$\mathrm{T}=$ treatment, $\mathrm{C} \times \mathrm{T}=\mathrm{crop} \times$ treatment interaction, aNDF=neutral detergent fibre analysed using heat-stable amylase

Silage fermentation was also affected by fermentation time (Table 2). In lucerne and Maize-LDM, the aNDF was similar between 4 and $60 \mathrm{~d}$ whereas there was a decrease in aNDF with time in Maize-HDM. In all three crops, the $\mathrm{pH}$ was lower at $60 \mathrm{~d}$. Lactic and acetic acid concentrations were higher at $60 \mathrm{~d}$ for lucerne and Maize-HDM, but similar between 4 and $60 \mathrm{~d}$ for Maize-LDM. Ethanol was higher in Maize-LDM at $60 \mathrm{~d}$ than $4 \mathrm{~d}$.

Table 2. Mean silage characteristics ( $\mathrm{g} \mathrm{kg}^{-1} \mathrm{DM}$ except as noted) by silage fermentation time across treatments.

\begin{tabular}{|c|c|c|c|c|c|c|c|c|c|c|}
\hline \multirow[b]{2}{*}{ Constituent } & \multicolumn{2}{|c|}{ Lucerne } & \multicolumn{2}{|c|}{ Maize-HDM $^{1}$} & \multicolumn{2}{|c|}{ Maize-LDM } & \multirow{2}{*}{$\begin{array}{l}\text { SEM } \\
C \times D\end{array}$} & \multicolumn{3}{|c|}{$p$-value } \\
\hline & $4 d$ & $60 \mathrm{~d}$ & $4 d$ & $60 \mathrm{~d}$ & $4 d$ & $60 d$ & & C & $\mathrm{D}$ & $C \times D$ \\
\hline $\begin{array}{l}\text { Dry matter } \\
\left(\mathrm{g} \mathrm{kg}^{-1}\right)\end{array}$ & 575 & 570 & 491 & 494 & 297 & 304 & 4.9 & $<0.001$ & 0.67 & 0.52 \\
\hline aNDF & 343 & 351 & 425 & 368 & 378 & 359 & 11.7 & 0.001 & 0.03 & 0.04 \\
\hline $\mathrm{pH}$ & 5.66 & 4.63 & 4.36 & 4.00 & 3.82 & 3.74 & 0.008 & $<0.001$ & $<0.001$ & $<0.001$ \\
\hline Lactic Acid & 10.4 & 49.3 & 23.8 & 41.5 & 42.7 & 46.0 & 1.75 & $<0.001$ & $<0.001$ & $<0.001$ \\
\hline Acetic Acid & 1.11 & 7.91 & 4.76 & 8.47 & 9.83 & 10.11 & 0.429 & $<0.001$ & $<0.001$ & $<0.001$ \\
\hline Ethanol & 0.59 & 0.92 & 2.82 & 3.85 & 4.99 & 12.39 & 0.368 & $<0.001$ & $<0.001$ & $<0.001$ \\
\hline
\end{tabular}

${ }^{1} \mathrm{HDM}=$ high dry matter, LDM=low dry matter, $\mathrm{SEM}=$ standard error of the mean, $\mathrm{C}=\mathrm{crop}, \mathrm{D}=$ days of fermentation, $\mathrm{C} \times \mathrm{D}=\mathrm{crop} \times \mathrm{day}$ interaction, aNDF=neutral detergent fibre analysed using heat-stable amylase 


\section{In vitro rumen fermentation}

There were few effects on the 9 and $24 \mathrm{~h}$ in vitro rumen fermentations of the wet-ground silages relative to treatment (Table 3). At $9 \mathrm{~h}$ with Maize-HDM, IVDMD was higher in LP than control. At $24 \mathrm{~h}$ in lucerne, MBY was greater in LP than control $(p=0.074)$. No other effects of treatment were observed. The highest IVDMD occurred in Maize-HDM and lowest in lucerne, both at 9 and 24 h. At 9 h, propionate was highest in Maize-LDM and lowest in lucerne whereas butyrate was highest in Maize-HDM and lowest in lucerne. At $24 \mathrm{~h}$, all three VFA measured were highest in Maize-HDM and lowest in lucerne. At 9 h, MBY was highest in Maize-HDM. By 24 h, MBY was highest in lucerne and lowest in Maize-LDM. There was no effect of silage fermentation time on any of these in vitro fermentation characteristics (data not shown).

Table 3. In vitro rumen fermentation profile and microbial biomass yield (MBY) of wet-ground silages at $9 \mathrm{~h}$ and $24 \mathrm{~h}$ averaged across silage fermentation times.

\begin{tabular}{|c|c|c|c|c|c|c|c|c|c|c|}
\hline \multirow[b]{2}{*}{ Constituent } & \multicolumn{2}{|c|}{ Lucerne } & \multicolumn{2}{|c|}{ Maize-HDM $^{1}$} & \multicolumn{2}{|c|}{ Maize-LDM } & \multirow{2}{*}{$\begin{array}{l}\text { SEM } \\
\mathrm{C} \times \mathrm{T}\end{array}$} & \multicolumn{3}{|c|}{$p$-value } \\
\hline & Control & $\mathrm{LP}$ & Control & $\mathrm{LP}$ & Control & $\mathrm{LP}$ & & $\mathrm{C}$ & $\mathrm{T}$ & $\mathrm{C} \times \mathrm{T}$ \\
\hline \multicolumn{11}{|l|}{$9 \mathrm{~h}$} \\
\hline IVDMD² 9h & 619 & 609 & 701 & 729 & 677 & 656 & 9.3 & $<0.001$ & 0.88 & 0.03 \\
\hline $\begin{array}{l}\text { Acetate } \\
(\mathrm{mM})\end{array}$ & 49.8 & 50.6 & 49.4 & 48.9 & 49.0 & 47.3 & 1.25 & 0.29 & 0.65 & 0.61 \\
\hline $\begin{array}{l}\text { Propionate } \\
\text { (mM) }\end{array}$ & 13.5 & 13.7 & 16.4 & 16.6 & 18.3 & 17.6 & 0.62 & $<0.001$ & 0.87 & 0.68 \\
\hline $\begin{array}{l}\text { Butyrate } \\
\text { (mM) }\end{array}$ & 6.7 & 6.6 & 12.1 & 12.2 & 10.1 & 10.3 & 0.31 & $<0.001$ & 0.86 & 0.95 \\
\hline $\begin{array}{l}\text { MBY } \\
\text { (mg/g DM) }\end{array}$ & 329 & 325 & 418 & 429 & 315 & 268 & 17.4 & $<0.001$ & 0.36 & 0.24 \\
\hline \multicolumn{11}{|l|}{$24 \mathrm{~h}$} \\
\hline IVDMD 24h & 645 & 661 & 846 & 836 & 768 & 760 & 11.5 & $<0.001$ & 0.94 & 0.47 \\
\hline $\begin{array}{l}\text { Acetate } \\
(\mathrm{mM})\end{array}$ & 53.8 & 52.7 & 73.0 & 71.8 & 60.9 & 62.2 & 1.18 & $<0.001$ & 0.72 & 0.50 \\
\hline $\begin{array}{l}\text { Propionate } \\
(\mathrm{mM})\end{array}$ & 14.6 & 15.0 & 26.2 & 26.5 & 20.7 & 21.2 & 0.71 & $<0.001$ & 0.52 & 1.00 \\
\hline $\begin{array}{l}\text { Butyrate } \\
(\mathrm{mM})\end{array}$ & 8.0 & 8.6 & 20.6 & 21.0 & 13.7 & 13.9 & 0.55 & $<0.001$ & 0.35 & 0.93 \\
\hline $\begin{array}{l}\text { MBY } \\
\text { (mg/g DM) }\end{array}$ & 314 & 347 & 241 & 241 & 196 & 193 & 8.3 & $<0.001$ & 0.15 & 0.07 \\
\hline
\end{tabular}

${ }^{1} \mathrm{HDM}=$ high dry matter, LDM=low dry matter, $\mathrm{LP}=$ treated with Lactobacillus plantarum, $\mathrm{C}=\mathrm{crop} ; \mathrm{T}=$ treatment, $\mathrm{C} \times \mathrm{T}=\mathrm{crop} \times$ treatment interaction, SEM=standard error of the mean

${ }^{2}$ IVDMD=In vitro dry matter digestibility, MBY=Microbial biomass yield estimated by the difference of in vitro true digestibility and in vitro apparent digestibility (Blümmel et al. 1997).

In vitro rumen fermentation of the water and ethanol silage extracts had an effect on MBY and GP, but the effect was different among crops and between treatments (Table 4). The MBY of water extracts was greater in control than LP in lucerne, while no effect of treatment was observed in either maize. In contrast, the MBY of ethanol extracts was unaffected by treatment, but there were trends for greater MBY in LP than control in lucerne and the opposite in the two maizes. Averaging across crops and treatments, the MBY was $4.7 \%$ greater in the ethanol extract than the water extract (Table 4). The GP in the water extracts was not affected by treatment (Table 4). In the ethanol extracts, GP was higher in LP than control in lucerne and Maize-LDM.

Effects of treatment on the VFA profiles of the in vitro rumen fermentations of silage extracts were observed in the lucerne extracts (Table 5). The acetate concentrations from ethanol extracts of the LP treatment were higher than the LP water extract and both control extracts. Propionate concentrations were reduced in the ethanol extracts compared to the water extracts. Butyrate concentration was lower in the ethanol extracts of the control compared to the other extracts. There was no effect of silage fermentation time on VFA concentrations. However, there were significant interactions with treatment (data not shown); acetate and butyrate concentrations were lower in the control extracts at $4 \mathrm{~d}$ than at $60 \mathrm{~d}$ and than in the LP extracts at 4 and $60 \mathrm{~d}$, which were all similar. 
R.E. Muck et al. (2013) 22: 108-114

Table 4. Microbial biomass (MBY, $\left.\mathrm{mg} \mathrm{g}^{-1} \mathrm{DM}\right)$ and gas production (GP, $\mathrm{mL} \mathrm{g}^{-1} \mathrm{DM}$ ) from water or ethanol silage extracts and glucose after $24 \mathrm{~h}$ in vitro rumen fermentation.

\begin{tabular}{|c|c|c|c|c|c|c|c|c|c|c|}
\hline \multirow[b]{2}{*}{ Extract } & \multicolumn{2}{|c|}{ Lucerne } & \multicolumn{2}{|c|}{ Maize-HDM ${ }^{1}$} & \multicolumn{2}{|c|}{ Maize-LDM } & \multirow{2}{*}{$\begin{array}{l}\text { SEM } \\
\text { CXT }\end{array}$} & \multicolumn{3}{|c|}{$p$-value } \\
\hline & Control & LP & Control & LP & Control & LP & & C & $\mathrm{T}$ & $\mathrm{C} \times \mathrm{T}$ \\
\hline \multicolumn{11}{|l|}{ MBY } \\
\hline $\begin{array}{l}\text { Water } \\
\text { extract }\end{array}$ & 20.7 & 15.7 & 15.9 & 16.5 & 16.6 & 15.9 & 1.32 & 0.21 & 0.20 & 0.02 \\
\hline $\begin{array}{l}\text { Ethanol } \\
\text { extract }\end{array}$ & 16.4 & 18.8 & 19.9 & 18.1 & 17.1 & 15.7 & 1.32 & 0.21 & 0.20 & 0.02 \\
\hline $\mathrm{LP}^{-\mathrm{DA}^{2}}$ & \multicolumn{2}{|c|}{13.5} & \multicolumn{2}{|c|}{13.3} & \multicolumn{2}{|c|}{12.0} & 1.31 & 0.70 & & \\
\hline \multicolumn{11}{|l|}{ GP } \\
\hline $\begin{array}{l}\text { Water } \\
\text { extract }\end{array}$ & 35.2 & 36.0 & 19.8 & 21.3 & 25.4 & 27.2 & 1.06 & $<0.001$ & 0.02 & 0.08 \\
\hline $\begin{array}{l}\text { Ethanol } \\
\text { extract }\end{array}$ & 33.7 & 37.3 & 21.9 & 19.7 & 24.5 & 28.2 & 1.06 & $<0.001$ & 0.02 & 0.08 \\
\hline LP-DA & \multicolumn{2}{|c|}{24.7} & \multicolumn{2}{|c|}{16.8} & \multicolumn{2}{|c|}{21.6} & 1.49 & 0.01 & & \\
\hline
\end{tabular}

${ }^{1} \mathrm{HDM}=$ high dry matter, $\mathrm{LDM}=$ low dry matter, $\mathrm{LP}=$ treated with Lactobacillus plantarum, $\mathrm{C}=\mathrm{crop}, \mathrm{T}=$ treatment, $\mathrm{C} \times \mathrm{T}=\mathrm{crop} \times$ treatment interaction, SEM=standard error of the mean

${ }^{2} \mathrm{LP}-\mathrm{DA}=$ direct addition of $\mathrm{LP}$ to rumen inoculum, no silage extract.

Table 5. Volatile fatty acid concentrations (mM) from water or ethanol lucerne silage extracts and glucose after $24 \mathrm{~h}$ in vitro rumen fermentation.

\begin{tabular}{lllllll}
\hline & $\begin{array}{l}\text { Control } \\
\text { Water }\end{array}$ & Ethanol & Water & Ethanol & SEM & $p$-value \\
\hline Acetate & 37.2 & 37.9 & 36.1 & 41.4 & 0.38 & 0.001 \\
Propionate & 11.3 & 9.3 & 11.0 & 10.1 & 0.17 & 0.005 \\
Butyrate & 7.2 & 6.6 & 7.0 & 7.1 & 0.10 & 0.004 \\
\hline
\end{tabular}

${ }^{1} \mathrm{LP}=$ treated with Lactobacillus plantarum, SEM=standard error of the mean

The direct application of LP to the in vitro rumen inoculum produced less MBY and GP than the silage extracts (Table 4). Extracts for each crop were performed in separate in vitro runs and tubes with LP added directly to rumen fluid were included in each run. So, similar MBY and GP values for direct application of LP would be expected across crops. That was true for MBY but not GP, where GP was lower in the Maize-HDM in vitro runs than in the other two crops.

\section{Discussion}

A probiotic effect of silage microbial inoculants on animal performance was proposed by Weinberg and Muck (1996). Even though the mechanism by which silage microbial inoculants enhance animal performance has not been elucidated, better preservation of nutrients in the silage could explain in part the animal performance effect (Muck et al. 2007, Contreras-Govea et al. 2011). In the current study, the hypothesis was that a factor in inoculated silage that enhances rumen microbial activity should be extractable from silage. Therefore, three different crops harvested separately were inoculated with a specific strain of LP that has usually shown a positive effect on silage fermentation and animal performance (Kung et al. 2003).

Silage fermentation characteristics of the three crops with or without LP were typical of silages ensiled at high and more typical DM concentrations. Because of their high DM concentrations, the $\mathrm{pH}$ and fermentation products of lucerne and Maize-HighDM silages were different between day 4 and day 60, indicating that active fermentation by LAB was not complete after $4 \mathrm{~d}$ (Table 2). In contrast, there were no differences in silage fermentation characteristics in Maize-LDM between the two days with the exception of an increase in ethanol. Given that lactic acid did not increase between days 4 and 60, the increase in ethanol in the Maize-LDM silages may have been due to the activity of yeasts (McDonald et al. 1991). 
The LP treatment affected silage fermentation, compared to control, in lucerne but not appreciably in the two maize experiments. In lucerne, LP decreased $\mathrm{pH}$ and increased lactic acid compared to control (Table 1), and the effect was evident at both days 4 and 60 (data not shown). This is what would be expected when an inoculant like L. plantarum is used. For example, Filya et al. (2007) also reported lower $\mathrm{pH}$ and higher lactic acid in the inoculated lucerne silage compared with control when ensiled at high DM concentrations. In contrast, the only effect of LP on silage fermentation in Maize-HDM was a lower $\mathrm{pH}$ at day 4 (4.339 vs. 4.388), and in Maize-LDM a higher ethanol concentration at day 60 (15 vs. $\left.10 \mathrm{~g} \mathrm{~kg}^{-1} \mathrm{DM}\right)$. The lack of an inoculant effect is not uncommon. Muck and Kung (1997) in a survey of published studies reported that $60 \%$ of the time silage microbial inoculants decreased $\mathrm{pH}$ compared to uninoculated treatments. So, there are a substantial numbers of instances where an inoculant has not affected silage fermentation. In the case of Maize-LDM, the epiphytic LAB population was similar to the inoculant application rate and may have competed effectively with the inoculant. In Maize-HDM, the epiphytic LAB population was lower than the inoculant application rate. Perhaps other epiphytic bacteria such as enterobacteria dominated the early fermentation (Pahlow et al. 2003). Unfortunately the only microbial group analysed was the LAB.

The absence of a consistent effect of LP across crops on the in vitro rumen fermentation at $9 \mathrm{~h}$ and $24 \mathrm{~h}$ (Table 3 ) was not unexpected. Muck and Kung (1997) reported that a positive effect of inoculant treatment on in vitro true DM digestibility occurred in only $30 \%$ of the studies reviewed. In addition, Muck et al. (2007) reported no consistent effect of microbial inoculants on VFA composition of in vitro rumen fermentations of inoculated and untreated lucerne silages. The MBY at $9 \mathrm{~h}$ and $24 \mathrm{~h}$ in the current study did not show a consistent effect of LP across crops in contrast to our earlier study (Contreras-Govea et al. 2011). In Contreras-Govea et al. (2011), MBY was greater in the LP-treated silages than control across lucerne, maize and brown-midrib maize, but this effect was not consistent across the other inoculants tested. In our study, the MBY at $9 \mathrm{~h}$ was unaffected by inoculant treatment in any of the crops (Table 3). At $24 \mathrm{~h}$, MBY was higher in LP-treated lucerne silages than control silages $(p=0.074)$ whereas MBY was unaffected by treatment in the maize silages. Because the inoculant only affected the ensiling of the lucerne, the lack of treatment effects in the in vitro fermentations, particularly in the maize silages, is not surprising.

The hypothesis of this study was that if the mechanism that improves animal performance is produced by the microbial inoculant during fermentation, it should be extractable from the silage. The $80 \%$ ethanol extract was expected to remove more complex carbohydrates and $\mathrm{N}$ compounds than the water extract. Averaging across crops and treatments, MBY was $4.7 \%$ greater in the ethanol silage extract than water silage extract (Table 4). MBY from the extracts in maize were unaffected by treatment, but given the few effects of treatment in silage fermentation and in vitro fermentation of these silages, the lack of effect was expected. In the lucerne, the water extract of the control produced a higher MBY than the water extract of the LP silage and the ethanol extract of the control. These results suggest that the factor causing higher MBY in the LP-treated lucerne silage at $24 \mathrm{~h}$ in vitro fermentation is not water-soluble. While there was only a numerical trend for MBY to be higher in the ethanol extract of LP-treated lucerne silages compared to control, the ethanol extracts from the LP-treated lucerne silages produced more GP, acetate, propionate and butyrate than the control ethanol extracts (Tables 4 and 5). Such results stand in contrast to the in vitro rumen fermentations of the silages in this study and earlier ones (Muck et al. 2007, Contreras-Govea et al. 2011) where LP-treatment had no effect on or reduced GP and had little or no effect on VFA production. Consequently these results suggest that the substances causing increased MBY in in vitro fermentations of LP-treated silages were in neither the water nor ethanol extract.

Finally, MBY and GP from direct addition of LP to in vitro rumen fluid were lower than silage extracts (Table 4). These results suggest that the inoculant $L A B$ are not having any direct effect on in vitro rumen fermentation or at least that the extracts are providing more fermentable substances than the bacteria themselves.

\section{Conclusion}

In this study, Lactobacillus plantarum MTD/1 appeared to dominate in only one of the three crops ensiled, a lucerne. In that crop, in vitro rumen fermentation of the silages produced more MBY at $24 \mathrm{~h}$ in the LP-treated silages, consistent with earlier studies. In vitro fermentation of the water extracts of the lucerne silages produced no significant treatment differences in fermentation products with the exception of reduced MBY in the LP-treated extracts, indicating the factor affecting in vitro fermentation of the inoculated silages was not in the water extract. The ethanol extracts produced in vitro results that were also not consistent with the in vitro results of the silages. Consequently it appears that the factor in in vitro fermentation of inoculated silages causing increased MBY was in neither the water or ethanol extracts. However, there is the need for further research to confirm these results. 


\section{Acknowledgements}

The authors wish express their appreciation for the technical assistance of U.C. Hymes-Fecht and J.A. Boyd.

\section{References}

Blümmel, M., Makkar, H.P.S. \& Becker, K. 1997. In vitro gas production: a technique revisited. Journal Animal Physiology and Animal Nutrition 77: 24-34.

Contreras-Govea, F.E., Muck, R.E., Mertens, D.R. \& Weimer, P.J. 2011. Microbial inoculant effects on silage and in vitro ruminal fermentation, and microbial biomass estimation for alfalfa, bmr corn, and corn silage. Animal Feed Science and Technology 163: 2-10.

Filya, I., Muck, R.E. \& Contreras-Govea, F.E. 2007. Inoculant effects on alfalfa silage: Fermentation products and nutritive value. Journal of Dairy Science 90: 5108-5114.

Gollop, N., Zakin, V. \& Weinberg, Z.G. 2005. Antibacterial activity of lactic acid bacteria included in inoculants for silage and in silages treated with these inoculants. Journal of Applied Microbiology 98: 662-666.

Huhtanen, P., Nousiainen, J.I., Khalili, H., Jaakkola, S. \& Heikkila, T. 2003. Relationships between silage fermentation characteristics and milk production parameters: analyses of literature data. Livestock Production Science 81: 57-73.

Jaakkola, S., Rinne, M., Heikkila, T., Toivonen, V. \& Huhtanen, P. 2006. Effects of restriction of silage fermentation with formic acid on milk production. Agricultural and Food Science 15: 200-218.

Kung, L., Jr. \& Muck, R. E. 1997. Animal response to silage additives. In Silage: Field to Feedbunk. NRAES-99. Ithaca, NY, USA: Northeast Regional Agric. Engng. Service, p. 200-210.

Kung, L., Jr., Stokes, M. R. \& Lin, C. J. 2003. Silage additives. In: Buxton, D.R., Muck, R.E. \& Harrison, J.H. (eds.). Silage Science and Technology. Agronomy Monography no. 42. Madison, WI, USA: ASA-CSSA-SSSA. p. 305-360.

McDonald, P., Henderson, A.R. \& Heron, S.J.E. 1991. The Biochemistry of Silage. 2nd ed. Marlow, Bucks, UK: Chalcombe Publications. $340 \mathrm{p}$.

Muck, R. E. \& Dickerson, J. T. 1988. Storage temperature effects on proteolysis in alfalfa silage. Transactions of the ASAE 31: 1005-1009.

Muck, R.E., Filya, I. \& Contreras-Govea, F.E. 2007. Inoculant effects on alfalfa silage: in vitro gas and volatile fatty acid production. Journal of Dairy Science 90: 5115-5125.

Muck, R.E. \& Kung Jr., L. 1997. Effects of silage additives on ensiling. In: Silage: Field to Feedbunk. NRAES-99. Ithaca, NY, USA: Northeast Regional Agric. Eng. Service. p. 187-199.

Pahlow, G., Muck, R.E., Driehuis, F., Oude Elferink, S.J.W.H. \& Spoelstra, S.F. 2003. Microbiology of ensiling. In: Buxton, D.R., Muck, R.E., \& Harrison, J.H. (eds.). Silage Science and Technology. Agronomy Monography no. 42. Madison, WI, USA:ASA-CSSA-SSSA. p. 31-94

SAS Inc., 2001. SAS ${ }^{\circledR}$ User's Guide: Statistics, Version 9.1 Edition. Cary, NC, USA: SAS Inc.

Weimer, P.J., Dien, B.S., Springer, T.L. \& Vogel, K.P. 2005. In vitro gas production as a surrogate measure of the fermentability of cellulosic biomass to ethanol. Applied Microbiology and Biotechnology 67: 52-58.

Weinberg, Z.G., Chen, Y. \& Gamburg, M. 2004. The passage of lactic acid bacteria from silage into rumen fluid, in vitro studies. Journal of Dairy Science 87: 3386-3397.

Weinberg, Z.G. \& Muck, R.E., 1996. New trends in development and use of inoculants for silage. FEMS Microbiology Reviews 19: 53-68.

Weinberg, Z.G., Muck, R.E. \& Weimer, P.J. 2003. The survival of silage inoculant lactic acid bacteria in rumen fluid. Journal of Applied Microbiology 94: 1066-1071. 